\title{
Sustainable Water Resources Management for Food Security in Kenya: Case of Bwathonaro Catchment
}

\author{
Chris A. Shisanya*, Simon M. Onywere, Joy A. Obando \\ Chris A. Shisanya, Department of Geography, Kenyatta University, Nairobi, Kenya \\ Email: *shisanya.christopher@ku.ac.ke
}

How to cite this paper: Shisanya, C.A., Onywere, S.M. and Obando, J.A. (2017) Sustainable Water Resources Management for Food Security in Kenya: Case of Bwathonaro Catchment. Open Access Library Journal, 4: e3524.

https://doi.org/10.4236/oalib.1103524

Received: March 14, 2017

Accepted: May 8, 2017

Published: May 11, 2017

Copyright $\odot 2017$ by authors and Open Access Library Inc.

This work is licensed under the Creative Commons Attribution International License (CC BY 4.0). http://creativecommons.org/licenses/by/4.0/

\section{Open Access}

\begin{abstract}
Food security is important in Kenya today. Bwathonaro sub-catchment in Tana catchment is experiencing food insecurity and severe water related challenges due to high population pressure and over-reliance on irrigated agriculture for livelihood. Bwathonaro river supports irrigated agriculture, which is a major source of livelihood for people in the watershed. These challenges include: water pollution, inappropriate solid waste disposal, illegal water abstraction and/or over-abstraction of water, inefficient irrigation practices, encroachment on and drainage of wetlands as well as inappropriate use of agrochemicals in wetlands. The specific objectives of the study were to 1) document current status of water resource use; 2) propose a strategy for enhancing subsistence food crop farming within the existing khat (miraa) farming system; 3) promote efficient irrigation systems that reduce water use conflict and enhance equitable distribution, and 4) work with community to improve water quality and quantity. The study adopted a four-pronged approach in the data collection procedures, namely: socio-economic surveys, participatory approaches, biophysical data and geospatial tools. Results showed that water use conflicts are persistent in the catchment. However, one Water Resource User Association (WRUA)-BWARUA, has shown consistent progress towards managing water resources for food security. The WRUA has undertaken a number of activities including ensuring that water abstractors observe permit conditions, undertaking surveillance of polluters, awareness creation on protection of wetlands, springs and river banks among other activities in the catchment. The impact of these activities has been positive and includes: reduction of conflict over water, reduction in pollution, more water flowing downstream and more water availability in the catchment for diverse uses including irrigation for agriculture, livestock and wildlife. Such practices could be used in other sub-catchments of Kenya as showcases to facilitate the sustainable use of scarce water resources for the benefit of all stakeholders.
\end{abstract}




\section{Subject Areas}

Food Science \& Technology

\section{Keywords}

Bwathonaro, Food Security, Water Resources, Watershed Management

\section{Introduction}

The [1] states explicitly that the world has a water crisis. Poverty is seen as both a symptom and a cause of the water crisis. One of the Millennium Development Goals (MDGs) was to halve the proportion of people without access to clean and safe drinking water. Africa holds $11 \%$ out of the available fresh water which supports $13 \%$ of the world population in the continent. Water is a key driver of sustainable growth and poverty alleviation, and an essential input to production-agriculture, industry, energy, transport and is a basic requirement for healthy people and ecosystems [2]. Fighting global poverty and reducing hunger are at the height of the global development effort, as seen in the MDGs. High population growth occurs in developing countries which are home to close to one billion malnourished people [3]. In the developing countries, $70 \%$ of the poor live in rural areas where productions rely on rain-fed agriculture. Freshwater availability is seen as a limiting factor in food production and livelihood improvement. Meeting the MDGs particularly in poverty-stricken, water scarcity prone regions such as the semi-arid and dry sub-humid savannah regions in Africa were challenging.

In Kenya and since independence, poverty alleviation and reduction of inequalities have been some of the Government's major development objectives with the government putting in place a number of policies and programmes, which emphasize rapid economic growth. This is reflected in various government policy documents such as development plans, sessional papers and strategy papers. After four decades of trying to implement the development plans, the social and economic inequalities still persist. Poverty has increased from 3.7 million people affected in 1973 to 15 million people at the turn of this century. The elaborate 1997 welfare and monitoring survey in Kenya indicated that 53\% of people in rural areas were categorized as overall poor and $51 \%$ as food poor [4]. The poor are clustered into certain socio-economic categories that include small-scale farmers, pastoralists, agricultural and casual labourers, unskilled and semiskilled workers, female-headed rural households, the physically handicapped, HIV/AIDS orphans and street children [4]. Most people in these clusters are landless and lack of formal education.

Poverty situation in Kenya has spawned a wide gap between the rich and the poor. Statistics from Central Bureau of Statistics (CBS) show that income and social services are skewed in favour of the rich [5]. Inequalities are manifested in many forms with the country's $10 \%$ of the population controlling $42 \%$ of the to- 
tal wealth while the bottom $10 \%$ control less than $1 \%$ [5]. Further, regional inequalities within the country are extreme with for example the difference in life expectancy between Central and Nyanza Provinces being a staggering 19 years [6].

Research has identified a strong link between poverty in Kenya and lack of access to improved water supply and sanitation (WSS). Various key documents, notably the Participatory Poverty Assessment Study [7]; the National Poverty Eradication Plan [8]; the National Policy on Water Resources Management [9] and the Human Development Report on Addressing Social and Economic Disparities [10] have articulated this link and have set ambitious targets aimed at increasing access to resources. The planning approach adopted by the Poverty Reduction Strategy Plan [4] is that of bottom up with full involvement and participation of the stakeholders at the grassroots level. The reports and documents outline the scope of poverty and set targets for poverty reduction. They recognise that two-thirds Kenya is arid and semi arid and as a result, only about $160,000 \mathrm{~km}^{2}$ of land, most of which is situated in the wetter southwest area, is suitable for crop production that supports the current population of approximately 33 million. Future projections show that by the year 2025, per capita water availability will drop to $235 \mathrm{~m}^{3}$ from the current $650 \mathrm{~m}^{3}$ as a result of population growth [11] [12]. The level of water scarcity in some regions of the country has become a serious limiting factor for development activities. Consequently and since 2002, there has been a major reform in the water sector with clear roles for the different actors involved in the decentralized institutional framework that separates policy formulation from regulation and water services provision [11]. Most of the interventions measures put in place by the Government are however donor driven and are not integrated into the country's long-term budgetary and development goals, and consequently, they suffer from discontinuity and inconsistency.

Kenya with an estimated population of 32 million (in 2003) and a projected population of 43 million by the year 2015 faces enormous challenges in the management of its limited water resources. These challenges comprise:

- Water scarcity and effects of climate variability;

- Catchment degradation and underdevelopment of the available water;

- Poorly managed water resources assessment and monitoring programmes;

- Pollution and degradation of water resources;

- Trans-boundary water resources management;

- HIV/AIDS and underdevelopment of water resources.

The magnitude of the above issues and challenges and the severity of the water crisis that face Kenya, impact across most sectors of the economy, making water resources management a high priority area for the government. In recognition of the above issues and challenges, the water sector is being transformed in line with the national policies as outlined in the Water Act 2002 [13]; the Sessional Paper No. 1 of 1999 on National Water Policy on Water Resources Management and Development [8]; the National Poverty Reduction Strategy Paper of 2003 
[14]; and the Economic Strategy Paper for Wealth and Employment Creation [14]. The Catchment Management Strategy (CMS) is a tool that creates the framework for the management of the water resources and related land resources in the catchment and it outlines how the concept of integrated water resources management can be implemented at the catchment level.

In Bwathonaro watershed, the typical challenges that this project sort to address can be summarised as:

- Water pollution from washing, bathing and watering of animals directly in the river;

- Pollution of water from point sources (abattoirs, toilets, market centres, etc.);

- Inappropriate solid waste disposal in market centres;

- Illegal water abstraction and over-abstraction of water;

- Inefficient irrigation practices relaying on open furrow system that lead to water loss to underling porous formations;

- Encroachment on and drainage of wetlands/Inappropriate use of agro-chemicals within the wetlands;

- Introduction of eucalyptus species that are "high water spenders";

- Severe soil erosion on the farms, footpaths and roadsides;

- Lack of information on the water resource (water quantity, quality, rainfall, water use, sediment yield);

- Periodic human and wildlife conflicts;

- Dependence on a single external source of water.

With the above challenges this study aimed to assure availability of water resources for the well being of communities in the Bwathonaro watershed through catchment protection and to ensure availability of good quality water and sustainable management of the environment. The study carried out an integrated watershed management plan with BWARUA towards an environmentally and socio-economically healthy watershed that benefits the communities living within the Bwathonaro watershed. The goal of this research was to enhance water resource management as a national food security strategy in Bwathonaro watershed, Meru County. The objectives guiding this study were: 1) to document the current status of water resource use in Bwathonaro watershed, 2) to propose a strategy for enhancing subsistence food crops within the existing khat (miraa) farming system in the Bwathonaro watershed, 3) to promote efficient irrigation systems that will reduce conflict over water resources and increase equitable distribution in the watershed, and 4) to work with the community and put in place mechanisms to improve water quality and quantity.

\section{Materials and Methods}

\subsection{The Study Area}

Geographically, the Bwathonaro watershed is bounded by latitude $37^{\circ} 53^{\prime} 00^{\prime \prime} \mathrm{E}$ and $38^{\circ} 05^{\prime} 00^{\prime \prime} \mathrm{E}$ and $0^{\circ} 12^{\prime} 00^{\prime \prime} \mathrm{N}$ and $0^{\circ} 21^{\prime} 00^{\prime \prime} \mathrm{N}$ with the Nyambene Hills as its catchment (Figure 1). The population is estimated at 46,000 people, who are mainly agriculturalists. The altitude ranges from 2060 m a.s.l. in Ngawa Hills to 


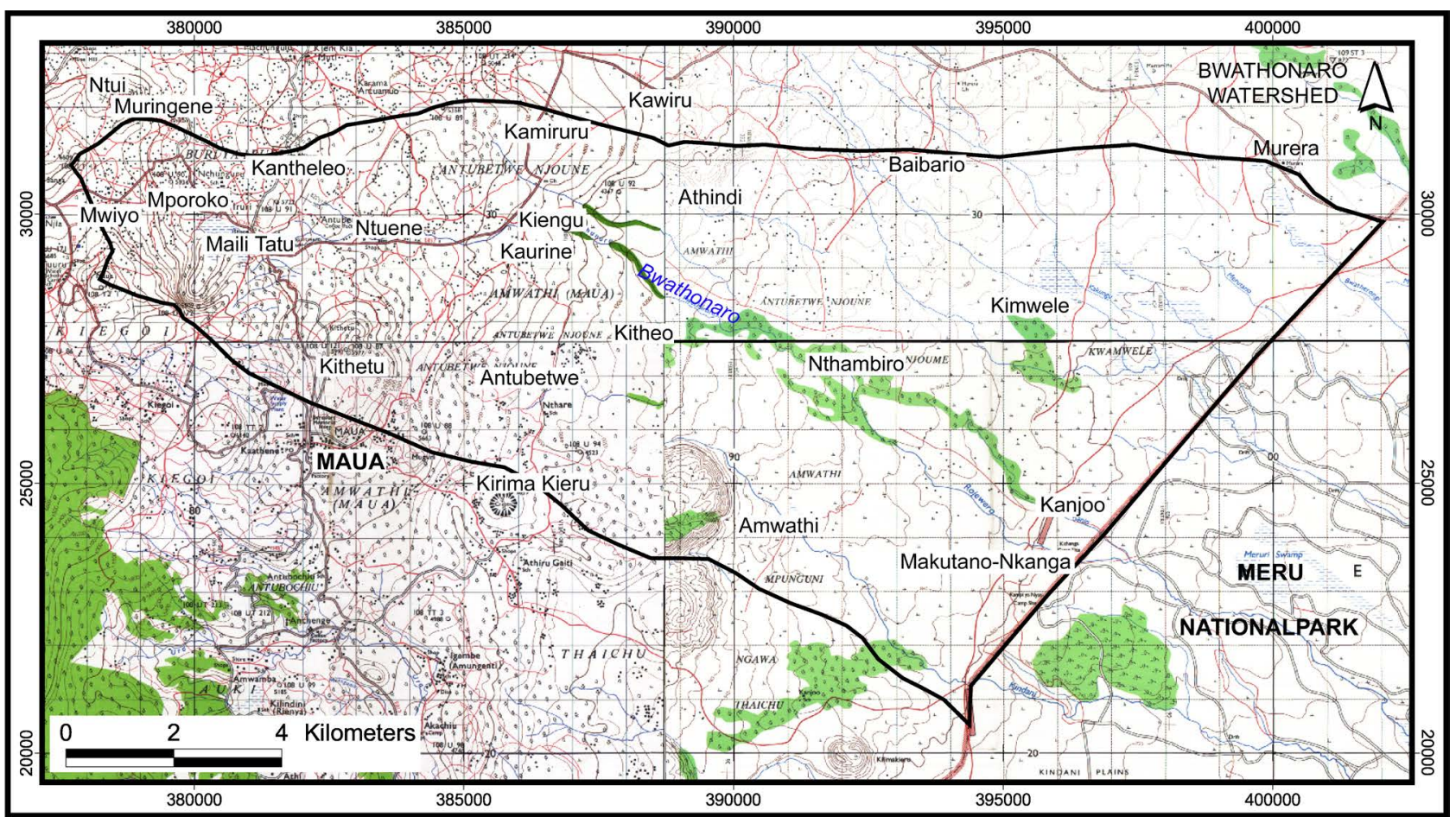

Figure 1. Bwathonaro watershed.

$700 \mathrm{~m}$ a.s.l. at the park area. The climatic conditions of the catchment range from humid to semi-arid. Rainfall is bimodal coming during the long rainy season of March to May and the short rainy season from October to December and varies from about $1300 \mathrm{~mm}$ at the hill tops to $600-700 \mathrm{~mm}$ in the plains around Amwathi [15]. The months of January to February and August to October are dry and very challenging with the area experiencing decreased water availability.

The geology of the catchment comprises mainly of basaltic volcanic rocks with tuffs and pyroclastics of Pleistocene Age. They are young geologically and of clastic nature and have poorly developed soils. Because of climatic variation with altitude, variable soils have developed. The soils are poorly consolidated and with the combination of steep slopes are highly susceptible to erosion. The sources of the drainage into the Bwathonaro catchment contain the porous rock surfaces which allow water to percolate into the deeper horizons underground. Because of this fact irrigation activities loose water from the open furrow structures developed for that purpose. The ground water table is very deep.

Livestock rearing is another important activity in the catchment and includes the keeping of cattle, goat, sheep, donkey and chicken. Donkeys are also an important form of transport, particularly for firewood, water and other goods to the market within the catchment. Market centres such as Muringene, Nthambiro, Kiengu and Kanjoo have grown mainly through miraa trade. The main source of energy for cooking in the homesteads within the catchment is firewood. The demand for firewood has lead to depletion of indigenous tree species, scarcity of wood resources, deforestation, high prices and introduction of eucalyptus species. Additionally, women are forced to walk longer distances to collect 
firewood.

The data in Table 1 provides a summary of Bwathonaro catchment characteristics.

\subsection{Methods}

\subsubsection{Primary and Data Collection}

The research adopted a four pronged approach in the data collection procedures. These included socio-economic surveys, participatory approaches, biophysical data and geospatial data. A socio-economic baseline survey was being undertaken in order to document the current status of water resource use in Bwathonaro watershed. This was linked to the existing livelihood strategies and the interventions to food security in the project area. The major concern was the management of the water resources in relation to other natural resources that impact on food production. The local stakeholders were involved in the identification of constraints, the definition and the selection of potential solutions concerning the water resource use in the watershed. The local community were involved in the study through participatory research methods, which included key informants, in-depth and household interviews and focus group discussions (FGDs). These participatory approaches helped to capture the issues related to water resource use and food insecurity from the participants view points.

Modern geospatial tools of Remote Sensing and Geographical Information Systems were used in mapping and assessing the resources in the watershed which impact food security. This was done in consultation with the Regional Centre for Mapping of Resources for Development at Kasarani, Nairobi. Site surveys were carried out on the physiography, geology, geomorphology, soils, hydrology and climate. In addition, information was obtained from relevant government departments. A geographical positioning system (GPS) was used in locating the various natural resources particularly water within a spatial context.

Table 1. Summary of the key features of the Bwathonaro watershed.

\begin{tabular}{cc} 
Catchment area & $149 \mathrm{~km}^{2}$ \\
Annual average rainfall & $\sim 900 \mathrm{~mm}$ \\
Surface water abstractions rates. & Not known \\
Groundwater abstractions rates. & Not known \\
Average borehole yield & Not known \\
Borehole specific capacity & Not known \\
Hydropower production & Nil \\
Average discharge during low flow & Not known \\
Altitude & $750-1800 \mathrm{~m} \mathrm{a.s.1.}$ \\
Average temperature & $18^{\circ} \mathrm{C}$ \\
Water demand & Not known \\
Estimated water demand by 2030 & Not known \\
Population & 46,000 \\
Population density & 350 persons $/ \mathrm{km}^{2}$ \\
\hline
\end{tabular}




\subsubsection{Secondary Data Collection}

Secondary data supplemented the primary data. These were derived from various sources such as desk study, internet, FBO, CBO, NGO and government policy and reports. Other secondary data were obtained from the aerial photographs, topographic, geological, hydrological maps as well as satellite imagery.

\section{Results and Discussions}

\subsection{Socio-Economic Activities}

The main economic activities in the catchment are subsistence and commercial farming. The commercial farming mainly involves the growing of khat (miraa), macadamia nuts, coffee, tea and horticulture. Subsistence farming involves the growing of maize, beans, potatoes, arrow roots, bananas, sugar cane, sweet potatoes, cassava, yams, and kales. Sorghum, millet and pigeon peas are grown mainly in the Lower Zone. In this area miraa is grown through irrigation during the dry season. Since the Lower Bwathonaro catchment is the only area where cultivation of miraa in the dry season is possible, market prices for miraa during the months of July, August, September and October are very high, making it a very profitable activity. This leads to conflicts among the miraa growers and other water users.

Livestock rearing is another important activity in the catchment and includes cattle, goat, sheep, donkey and chicken. Donkeys are also an important form of transport, particularly for firewood, water and other goods for the market. Markets such as Muringene, Nthambiro, Kiengu and Kanjoo have been developed mainly for the trading of miraa. The main source of energy for cooking in the homesteads within the catchment is firewood. The demand for firewood has lead to depletion of indigenous tree species, scarcity of wood resources, deforestation, high prices and introduction of eucalyptus species. Additionally, women are forced to walk longer distances to collect firewood. Due to water scarcity in parts of the catchment, women and children are forced to walk long distances (up to 5 $\mathrm{km}$ ) to fetch water. This has implications on other productive sectors of the local economy due to loss of precious time for other activities. It also has health implications on the young girls, which often develop contracted pelvis which affect their reproductive systems.

\subsection{Challenges in Bwathonaro Catchment}

The following water management related problems were identified in the Bwathonaro catchment:

1) Water pollution from washing, bathing and watering of animals directly in the river;

2) Pollution of water from point sources (abattoirs, toilets, market centres etc.);

3) Inappropriate solid waste disposal in market centres;

4) Illegal water abstraction and over-abstraction of water;

5) Inefficient irrigation practices; 
6) Encroachment on and drainage of wetlands/Inappropriate use of agro-chemicals in wetlands;

7) Introduction of eucalyptus species;

8) Soil erosion on the farms, footpaths and roadsides;

9) Lack of water resource information (water quantity, quality, rainfall, water use, sediment yield);

10) Human and wildlife conflicts.

Dependence on a single external source of water.

\subsection{Satellite Image Analysis Results}

From the assessment of the image data of the project area, one full scene of Landsat Thematic Mapper (TM) and Enhanced Thematic Mapper (ETM) path/ raw p168r060 adequately covered the study area.

The images met Landsat sensor parameters and area coverage $(185 \times 185$ $\mathrm{km}^{2}$ ).

- Focus area of study: Subsets of Bwathonaro Catchment;

- Issues of concern: Land use and settlement trends at the catchment, vulnerability of the communities to flood hazards and other impacts, sustainability of the livelihood systems based on land use policy and legislative framework governing the lives of the riparian communities;

- Vision: to utilize existing data for planning for sustainable management of the Bwathonaro watershed and wetland resources to improve the livelihood of the local communities and address the issue of poverty.

Image data sets were acquired from US Geological Survey (USGS) through Regional Centre for Mapping of Resources for Development (RCMRD), Nairobi and used for the interpretation of the status of land cover in Bwathonaro catchment and included:

\begin{tabular}{|c|c|c|c|}
\hline Year: 1976 & Year: 1987 & Year: 2005 & Year: 2003 \\
\hline MSS & TM & ETM & ETM \\
\hline L2_p180r60_2m1 & L5_p168r60_5t & L7_p168r060_7k2 & L7_1168060_060 \\
\hline 9760211 & 870225 & 0000221 & 20031214 \\
\hline \multicolumn{4}{|c|}{$\begin{array}{l}\text { - DTM Data from Active Sensors-Shuttle Radar Topographic Mis- } \\
\text { sion;(SRTM); } \\
\text { - Landsat mosaic FCC bands } 432 \text { in MrSID format; Mosaic ID Zone } \\
\text { N/S-37_loc; } \\
\text { - Scanned 1:50,000 scale topographic maps for the larger Nyambene hills } \\
\text { area (sheets 107_2,4 zone 37, 108_1,2,3,4-Zone 37, 109_1,2,3,4-zone 37, } \\
\text { 121_2,4-zone 37, 122_1,2,3,4-zone 37, 123_1,3 zone 37); }\end{array}$} \\
\hline
\end{tabular}

The Landsat TM (7 bands) and ETM (9 bands) images have spatial resolution of $28 \mathrm{~m}-30 \mathrm{~m}$ with the thermal band at $80 \mathrm{~m}$-resolution and covers $185 \times 185$ $\mathrm{km}$. The Landsat MSS ( 4 bands) image has $80 \mathrm{~m}$ resolution. Currently Landsat 7 
is in operation but one of its scanning mirrors has malfunctioned and therefore the current data comes with strip errors that though can be corrected, the images can only be used for visual interpretation.

The Digital Terrain Model (DTM) from Active Sensors-Shuttle Radar Topographic Mission. (SRTM) data is valuable for knowledge of earth surface topography and is of major importance to Earth Sciences, e.g. hydrology, geomorphology. The data was obtained free of charge from: http://seamless.usgs.gov/ and ftp://edcsgsg.cr.usgs.gov/pub/data/srtm/. The current status of SRTM DTM for Africa is the first continuous large-scale homogeneous product and at 90-meter vertical resolution with a relative vertical accuracy of less than 10 meters, the data offers a great improvement compared to other existing global DTM of $1 \mathrm{~km}$ horizontal resolution from USGS.

All the Landsat satellite data had all the image bands and are in Geotiff Format. The reference projection for the study site is UTM zone 37, Datum: WGS84, Map Units: Meters, Central Meridian: $39^{\circ}$, Reference Latitude: Equator $\left(0^{\circ}\right)$, Scale Factor at Origin: 0.9996, False Easting 500,000, False Northing: 0. Preprocessing and identification of the band combinations that can give the best visual interpretation of the image subsets has been done. An example of the various image band combinations for the larger environment of the Bwathonaro catchment subset of scene p168r060 is shown in Figure 2.

\subsection{Geo-Referencing}

The satellite image of 1976, 1987, 2000 and 2003 geo-referenced against scanned topographic map at a scale of $1 / 50,000$ using a number of control points. The data was written to the Universal Transverse Mercator (UTM) with WGS84 as datum projection. Second order polynomial transformation and nearest neighbour re-sampling method was be used for this process.

\subsection{Image to Image Registration for the Year 1987, 2000, and 2003 Images}

The satellite images of 1987, 2000, and 2003 were co-registered to one another. This process, called image to image registration, is usually used for time-series image analysis. It ensures that the pixel grids of the images of the 1987, 2000, and 2003 (all with $30 \mathrm{~m}$ spatial resolution) conform to one another hence enabling pixel by pixel comparison of the images. Since the Landsat Multi-spectral Scanner (MSS) image of 1976 image has a resolution of $80 \mathrm{~m}$ it could not be utilized for similar registration but never the less the data was used to assess the status of land cover in that period. In this study, the satellite images were composited to a false colour composites FCC using band 4 (red), band 3 (green) and band 2 (blue). In this band combination the red colour represents dense vegetation, whilst the green/blue colour will mean very scattered vegetation cover or no vegetation cover or bare ground, in a Pseudo-colour composite of bands.

\subsection{Image Interpretation}

The key areas of the image interpretation included mapping forest cover and its 
The Bwathonaro Watershed Landsat image 11th Feb 1976

$37^{\circ} 55^{\prime}$

$38^{\circ} 00^{\prime}$

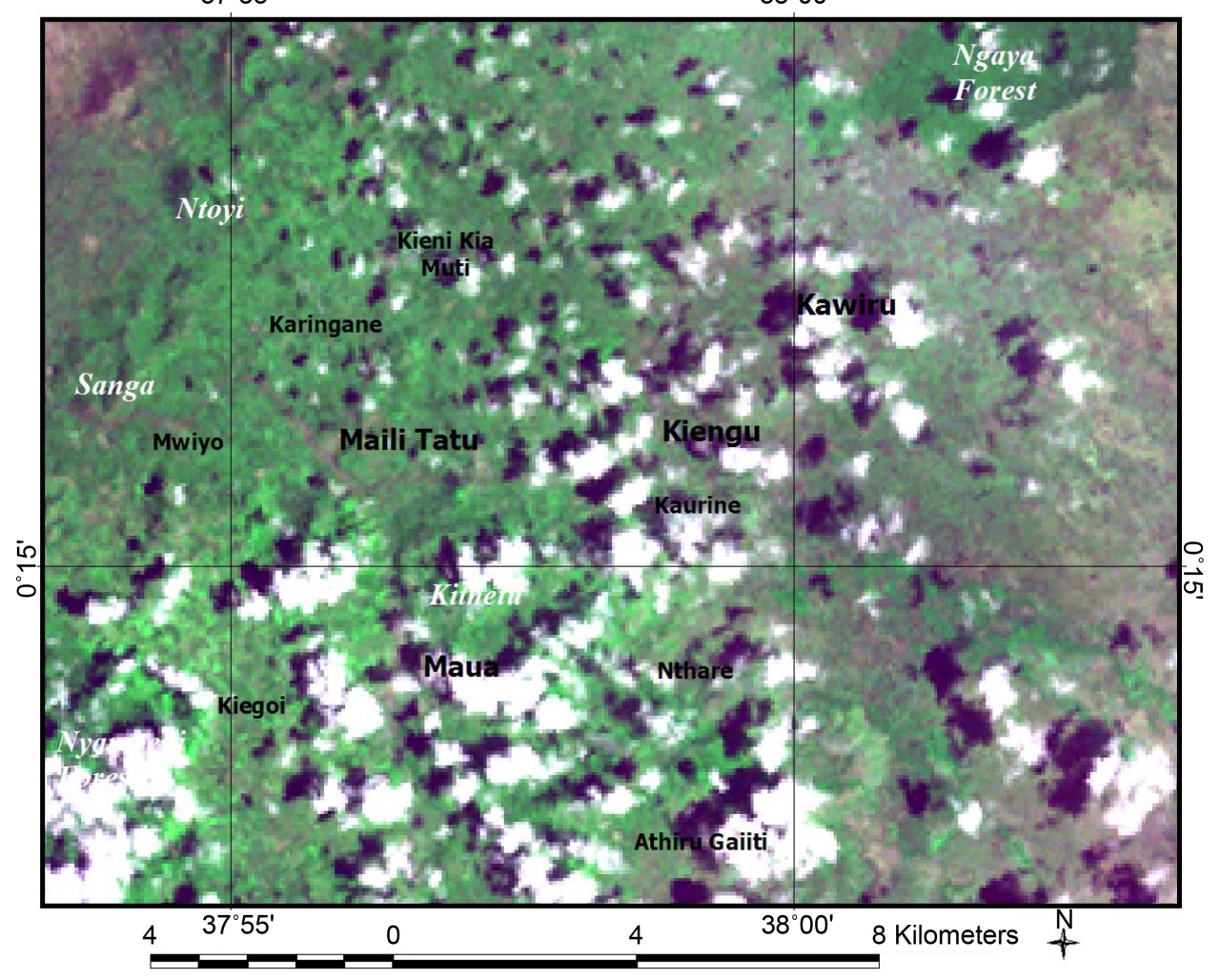

(a)

The Bwathonaro Watershed Landsat image 25th Feb 1987

$37^{\circ} 55^{\prime}$

$38^{\circ} 00^{\prime}$

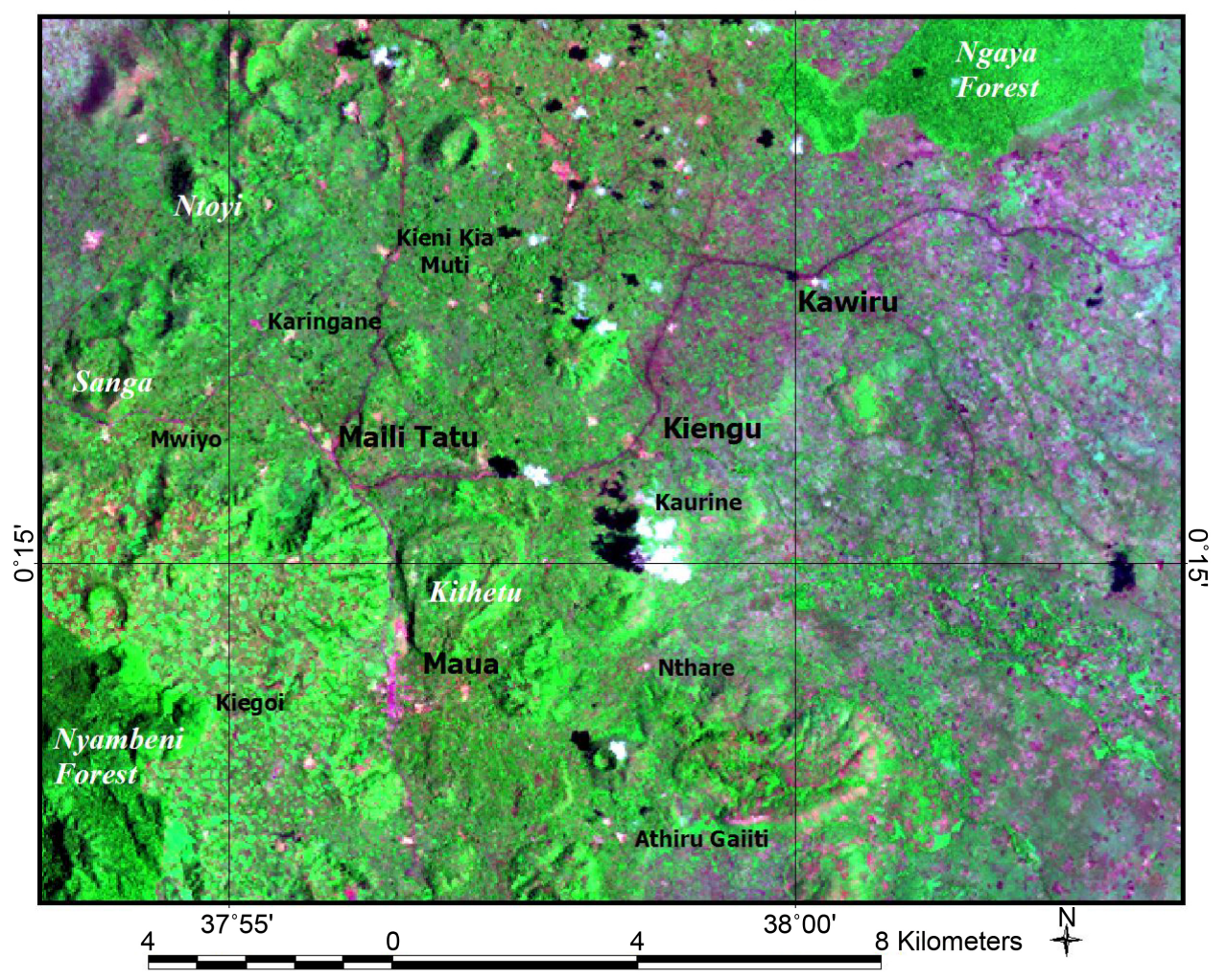

(b) 


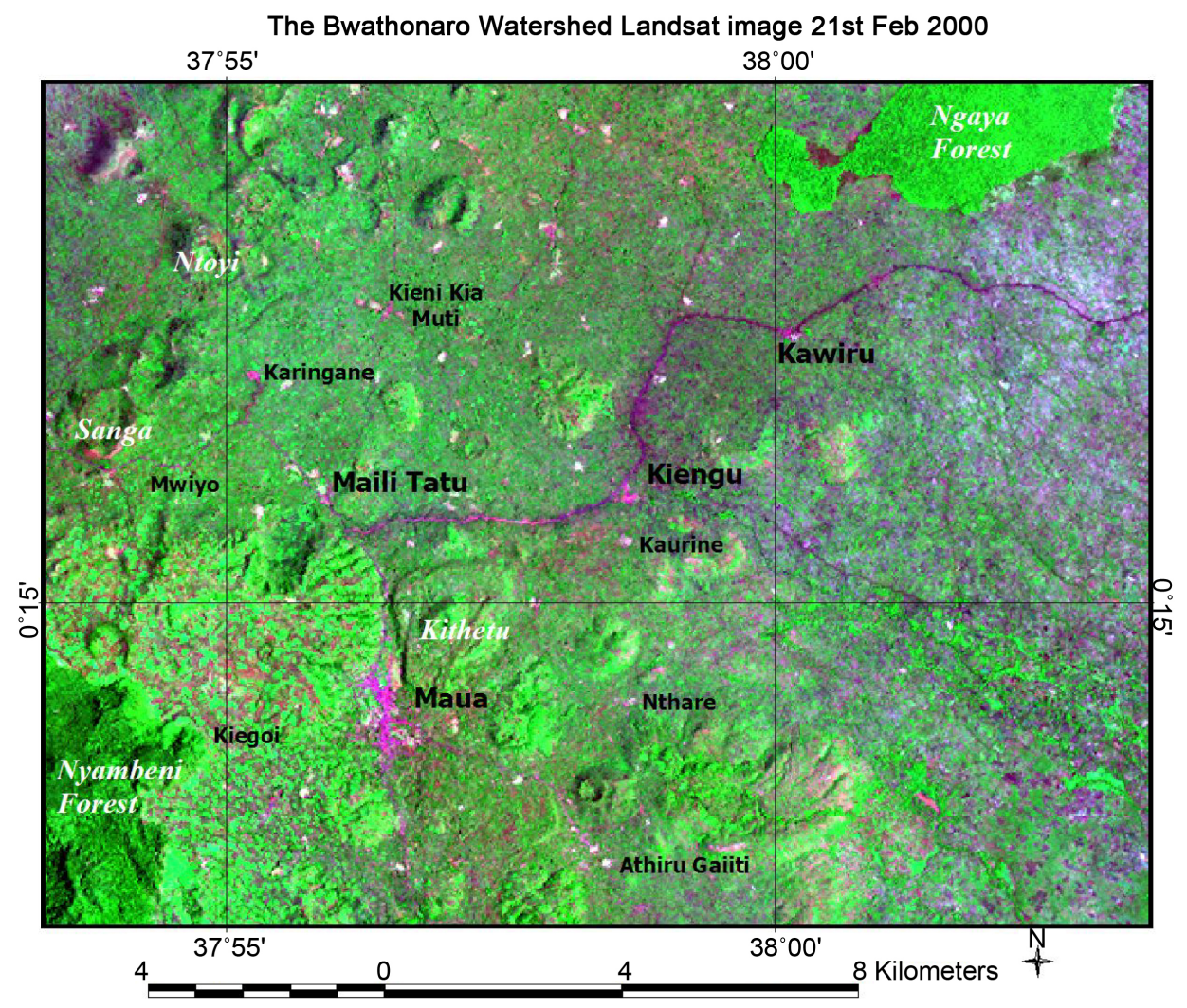

(c)

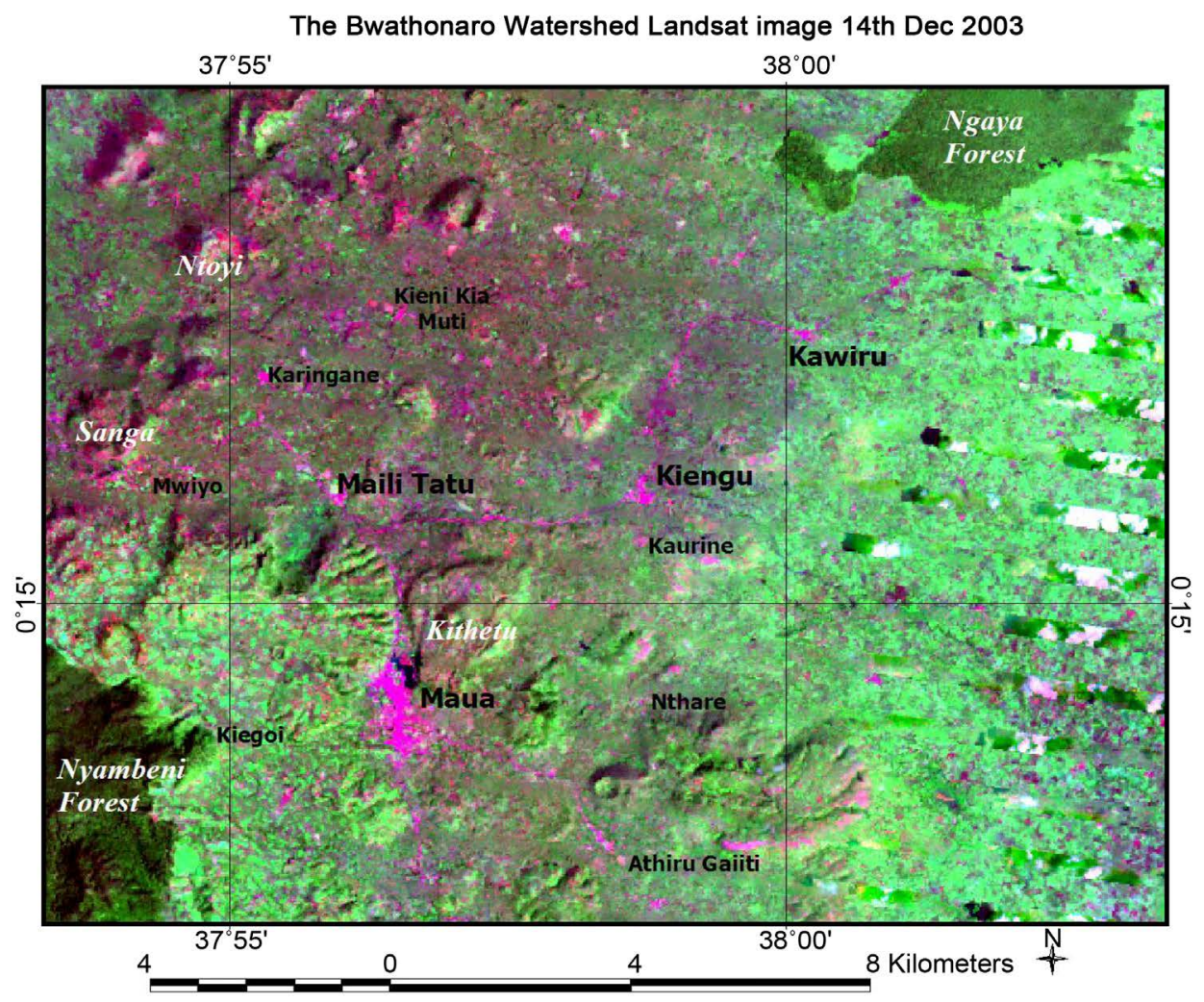

(d)

Figure 2. (a)-(d) the result of different band combinations of Landsat ETM data of the 2000 image and displayed using red, green blue colour redentions. 
changes and assessment of impacts of the forest loss on the local rainfall patterns and stream discharge. Remotely sensed data based on the pseudo-colour image composited using bands 742 RGB where vegetation appeared in green was used for interpretation because the colour composite is understood by the Bwathonaro community as it represents the colour of the natural vegetation. The FCC was used to map the forest cover and its changes between 1976 and 2008.

The image analysis was done at two levels: mapping forest cover and its changes and assessment of impacts of forest cover loss on the hydrological processes between 1976 and 2008. Satellite images of 1976, 1987, 2000, and 2003 from Landsat were used for detection of changes in the forest cover. The results are shown in Figure 3 and Table 2.

Change detection will be enhanced by conducting field visits to the area to make ground truthing. Rainfall and stream flow data available from existing measurements within the catchment area (such as at weather stations and stream gauges) will be used to illustrate hydrological alterations which will be correlated to forest cover change to establish the type or nature of relationship and the strength of relationship.

The destruction of the forest cover is reflected in the reduced green vegetation cover over the period of the images considered: 1976, 1987, 2000 and 2003. This

Table 2. Land cover types in Bwathonaro watershed.

\begin{tabular}{ccc}
\hline $\begin{array}{c}\text { Land cover classes in Bwathonaro } \\
\text { Sub-catchment }\end{array}$ & Area in $\mathrm{Km}^{2}$ & $\begin{array}{c}\text { Percentage of the total } \\
\text { area (\%) }\end{array}$ \\
\hline Bare ground & 7.31 & 1.11 \\
Closed grassland & 20.682 & 3.15 \\
Closed shrubs & 194.779 & 29.70 \\
Deforested & 2.665 & 0.40 \\
Forest & 35.419 & 5.40 \\
Grassland & 97.284 & 14.83 \\
Indigenous forest & 45.434 & 6.93 \\
Mountain vegetation & 1.633 & 0.25 \\
Open Shrubs with soil & 1.062 & 0.16 \\
Open grassland & 34.599 & 5.28 \\
Open shrubs & 135.066 & 20.60 \\
Plantation forest & 0.791 & 0.12 \\
Riverine trees & 12.154 & 1.85 \\
Rocks & 2.588 & 0.39 \\
Scattered shrubs & 19.171 & 2.92 \\
Shrubs & 15.115 & 2.30 \\
Urban area & 2.583 & 0.39 \\
Very open shrubs & 22.182 & 3.38 \\
Wetland & 5.255 & 0.80 \\
\hline & 655.774 & 100 \\
\hline
\end{tabular}




\section{The Bwathonaro Subcatchment Water Divide and Land CoverTypes}

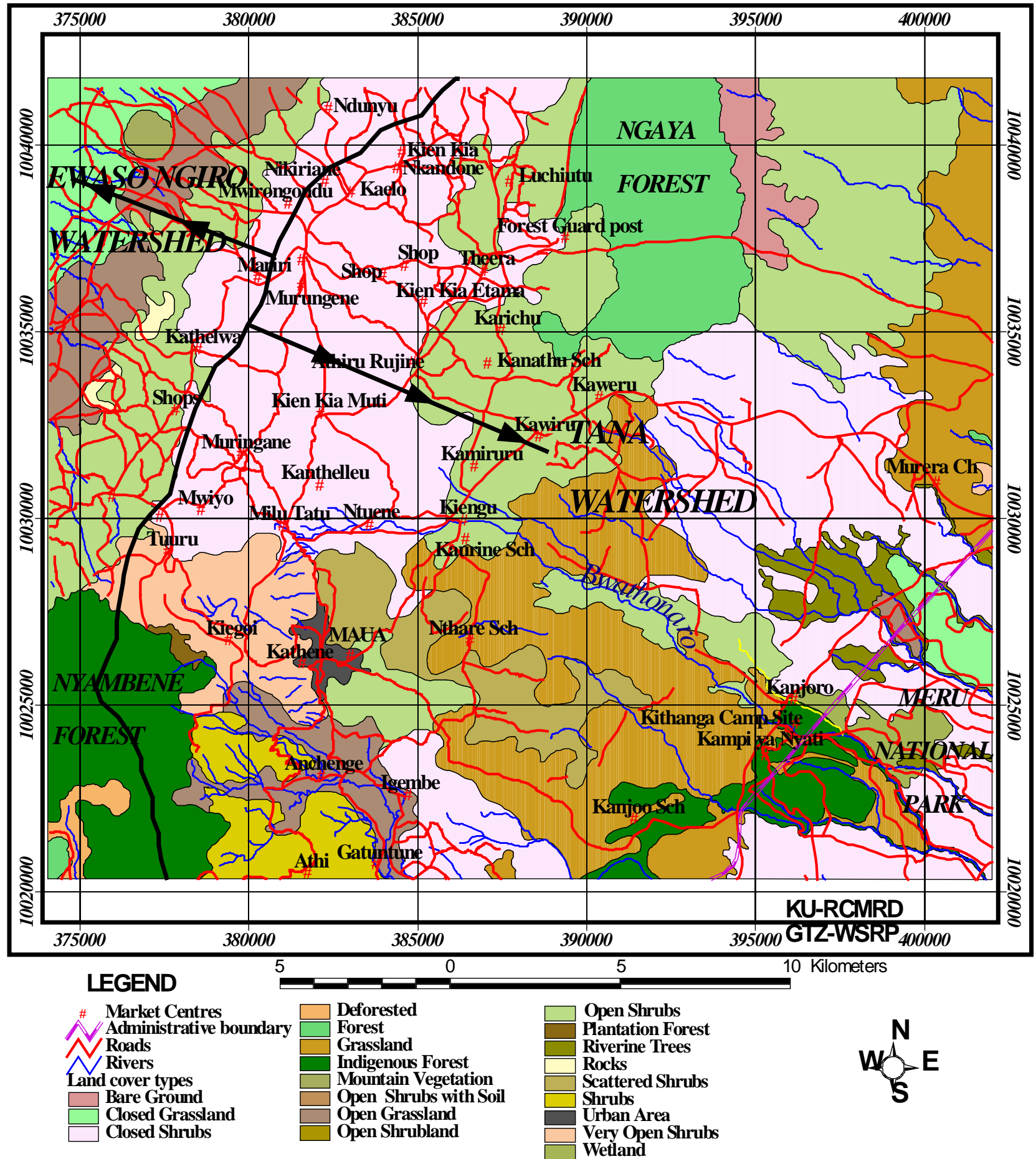

Figure 3. Land cover types in Bwathonaro watershed.

is threatening the hydrological functions, endangering water supplies for the community in the Bwathonaro watershed. The exposed soils may also cause severe siltation, flooding, affecting dry season flows and disrupting socio-economic activities such as irrigation. The downstream habitat quality may also be affected considering the increased settlement and encroachment into the ripar- 
ian environment.

\section{Conclusion}

So far, one Water Resource User Association (WRUA)-BWARUA, that is a partner in this project, established in Bwathonaro Sub-Catchment in Meru Sub-Region, Tana catchment, has shown consistent progress towards managing water resources for food security since its inception in 2005. The WRUA has undertaken a number of activities including ensuring that water abstractors observe permit conditions, undertaking surveillance of polluters of River Bwathonaro, awareness creation on protection of wetlands, springs and river banks among other activities in the catchment. The impact of these activities has been quite positive and they include: reduction of conflict over water, reduction in pollution, more water flowing downstream and more water availability in the catchment for diverse uses including irrigation for agriculture, livestock and wildlife. Such practices could be used in other sub-catchments as showcases to facilitate the sustainable use of scarce water resources for the benefit of all stakeholders.

\section{Recommendations}

This study recommends the following:

1) With regard to illegal and over abstraction of surface water, there is need to enforce the rules and regulations on water abstraction. This will include empowering Bwathonaro watershed communities to support enforcement of the law, renewal of permits, formation of water user groups and metering and paying for abstracted water.

2) Irrigation will continue to play a major role in the livelihoods of the Bwathonaro watershed communities. Inefficient irrigation practices such as use of unlined open furrows, leaking pipes and uncontrolled watering of Miraa trees is common within the watershed. Farmers will be encouraged to adopt more efficient irrigation practices such as piped conveyance, lined furrows and sprinkler and drip irrigation. Key will be establishment of water structures incentives, regulations and restrictions that will help, guide, influence and co-ordinate the farmers' behaviour for the efficient use of water for irrigation.

3) The wetlands serve to regulate the flow in the rivers and to trap sediment. During the dry season low flows are sustained by wetlands and in the rain season, flash floods are reduced and sediments are trapped. The wetlands in the catchment are threatened by encroachment for farming purpose, drainage and use of agrochemicals. The community should be sensitised on the importance of wetlands and discouraged from utilising them for agricultural activities.

4) Eucalyptus, which has been introduced in the catchment, is known to have high rate of water uptake resulting in reduction of water resources. It also causes deterioration of the soil structure, loss of fertility and hinders growth of other vegetation under its canopy. The introduction of a number and diversity of low water consuming tree species should be encouraged, especially environmentally friendly indigenous trees. 
5) Severe soil erosion is prevalent in the catchment leading to deep gullies on the hillsides and roadsides. Farmlands especially on steep slopes suffer from severe erosion. Infrastructures such as roads are damaged, thus limiting access to markets. Proposed interventions to curb erosion will include proper land use, soil and water management and appropriate engineering works. Implementation of riparian reserve requirements should be done according to recommendations in the Agriculture Act.

6) There is a general lack of data for effective water resources management. Instruments for collecting water related data should be installed in the catchment to improve existing ones. Kenyatta University, BWARUA and WRMA will work together to develop a plan for data collection and management.

Monitoring of water resources (rainfall, stream flow, groundwater, abstractions, and water quality) and catchment conditions should be done regularly in order to provide data that can be used to assess the impact of undertaking the above interventions. This should be coordinated by WRMA in collaboration with BWARUA.

\section{Acknowledgements}

The Commission for Higher Education (CHE) of Kenya is thanked for funding the study. Bwathonaro Water User Association (BWARUA) hosted the researchers in the watershed and provided very useful primary data.

\section{References}

[1] UN World Water Report (2003) Water for People, Water for Life. The United Nations World and Water Development Report, New York.

[2] International Research Institute (IRI) (2006) A Gap Analysis for the Implementation of the Global Climate Observing System Programme in Africa. Final Report.

[3] Swedish International Water Institute (SIWI) (2007) Rain: The Neglected Resources: Embracing Green Water Management Solutions, Stockholm, Sweden.

[4] Government of Kenya (GoK) (2001) Poverty Reduction Strategy Paper for the Period 2001-2004. Ministry of Planning and National Development, Nairobi Kenya.

[5] Central Bureau of Statistics-CBS (2000) Economic Survey of Kenya, 2000.

[6] Society for International Development-SID (2004) Pulling Apart, Facts and Figures on Inequality in Kenya, SID, Nairobi.

[7] Government of Kenya (GoK) (1997) The Second Participatory Poverty Assessment Study-Kenya. A Report Prepared by AMREF and the Human Social Services of the Office of the President and Ministry of Planning and National Development. Government Printer, Nairobi, Kenya.

[8] Government of Kenya (GoK) (1999) National Poverty Eradication Plan 1999-2015. Department of Development Co-Ordination, Ministry of Planning and National Development, Nairobi, Kenya. Government Printer.

[9] Government of Kenya (GoK) (1999) Sessional Paper No.1 of 1999 on National Policy on Water Resources Management. Government Printer, Nairobi, Kenya.

[10] UNDP (2002) Addressing Social and Economic Disparities. Human Development Report United Nations Development Programme, Nairobi, Kenya. 
[11] Water Resource Management Authority (WRMA) (2006) Catchment Management Strategy. Final Draft.

[12] Ngige, A. and Macharia, F. (2006) Kenya Water Policy Overview Paper, IT Power East Africa.

[13] Government of Kenya (GoK) (2002) The Water Act 2002 (Cap 372) Government Printer, Nairobi, Kenya.

[14] Government of Kenya (GoK) (2003) Kenya Participatory Impact Monitoring (KePIM); Perspectives of the Poor on the Credit and Extension Policies. Ministry of Finance and Planning, Nairobi, Government Printer.

[15] Jaetzold, R., Hornetz, B. and Shisanya, C.A. (2007) Farm Management Handbook of Kenya Vol II: Natural Conditions and Farm Management Information, Part B, Eastern Kenya. Ministry of Agriculture, Nairobi.

Submit or recommend next manuscript to OALib Journal and we will provide best service for you:

- Publication frequency: Monthly

- 9 subject areas of science, technology and medicine

- Fair and rigorous peer-review system

- Fast publication process

- Article promotion in various social networking sites (LinkedIn, Facebook, Twitter, etc.)

- Maximum dissemination of your research work

Submit Your Paper Online: Click Here to Submit

Or Contact service@oalib.com 